Article

\title{
Summer Changes in Water Mass Characteristics and Vertical Thermohaline Structure in the Eastern Chukchi Sea, 1974-2017
}

\author{
Yayu Yang ${ }^{1,2}$ (D) and Xuezhi Bai ${ }^{1,3, *}$ \\ 1 College of Oceanography, Hohai University, Nanjing 210098, China; yy.young@hhu.edu.cn \\ 2 Key Laboratory of Marine Hazards Forecasting, Ministry of Natural Resources, Hohai University, \\ Nanjing 210098, China \\ 3 Key Laboratory of Coastal Disaster and Defence (Hohai University), Ministry of Education, \\ Nanjing 210098, China \\ * Correspondence: xuezhi.bai@hhu.edu.cn; Tel.: +86-25-83787161
}

Received: 5 April 2020; Accepted: 15 May 2020; Published: 18 May 2020

\begin{abstract}
Hydrographic data from the World Ocean Database 2013 and the Chinese National Arctic Research Expedition were used to investigate the summertime changes in the eastern Chukchi Sea from 1974 to 2017. Owing to the Pacific inflow and timing of the sea ice retreat, water masses and vertical thermohaline structures in the eastern Chukchi Sea have changed but with regional differences. The entire eastern Chukchi Sea warmed up with significant temperature increase in the central shelf; however, the surface and bottom salinity in the southern, central, and northern shelves exhibited different trends. The northward extension of the Pacific Summer Water after 1997 influenced the summer hydrography significantly. Moreover, the data reveal changes in the characteristics of various water masses. Both Bering Summer Water (BSW) and Pacific Winter Water in the deeper layer became saltier, whereas the Alaskan Coastal Water in the upper layer became fresher after 1997. The previous definition of the BSW should be modified to include the warming water mass in the southern Chukchi Sea in the more recent years. Furthermore, the vertical thermohaline structure over the Chukchi shelves experienced considerable changes in its characteristics due to the combined effects of the Pacific inflow and surface forcing.
\end{abstract}

Keywords: Chukchi Sea; temperature; salinity; water mass; vertical thermohaline structure

\section{Introduction}

As one of the cold sources of the earth system, the Arctic plays a significant role in ocean circulation and the global climate. The Pacific water that flows poleward through the Bering Strait is primarily driven by the pressure difference between the Pacific and Arctic Ocean [1]. The poleward flowing Pacific water is a predominant source of freshwater, heat, and nutrients, thereby exerting a strong influence on the melting of ice, thermohaline structures, and ecosystem functioning of the Arctic Ocean [2-5]. As a peripheral sea of the Arctic, the Chukchi Sea has several important features: it provides the pathway for the Pacific water to flow into the Arctic and therefore becomes one of the most important regions to mix the Pacific and Arctic water; since it has a seasonal to perennial sea ice cover, the minimum ice extent and edge in this area have been widely used as indicators of global climate change [6,7]. The Pacific inflow water is transformed seasonally by oceanographic processes over the wide continental shelves, with far-reaching implications for Arctic halocline formation and basin dynamics: the changed water in the Chukchi Sea will eventually ventilate the upper halocline of the western Arctic Ocean. Furthermore, the southern Chukchi Sea is one of the most biologically productive regions of the world's oceans because of nutrients supplied by the Pacific inflow water [8,9]. 
The different water masses that reside on the Chukchi shelf during summer have been defined by their potential temperature and salinity in numerous previous studies (e.g., [1,10-13]). The three main classes of Pacific summer water (PSW) are Alaskan Coastal Water (ACW; $<$ approximately 32, $\mathrm{T}>3{ }^{\circ} \mathrm{C}$ ), Bering Summer Water (BSW; $\mathrm{T}=0-3{ }^{\circ} \mathrm{C}, \mathrm{S}=32-33$ ) [10], and Chukchi Summer Water (CSW; $\mathrm{T}>0{ }^{\circ} \mathrm{C}, \mathrm{S}=$ approximately $\left.31-32\right)[11,12]$. The ACW is transported seasonally by the Alaskan Coastal Current (ACC) to the eastern-most part of the strait. The BSW is a mixed water mass, which occupies the bulk of the central Chukchi Sea [2]. The CSW, colder than the ACW and fresher than the BSW, is a combination of the warm and fresh PSW, and the cold and salty winter water. In addition, the Pacific Winter Water (PWW) is defined as water with a temperature below $-1.6{ }^{\circ} \mathrm{C}$ and salinity greater than 31.5 [13]. The PWW is produced by cooling and brine rejection when ice forms during winter. The sea ice meltwater/river runoff (SMW, usually defined based on $24 \mathrm{~kg} \cdot \mathrm{m}^{-3}$ isopycnal) [14] is typically observed in the upper part of the water column (usually shallower than $15 \mathrm{~m}$ ) [13].

In recent decades, the Arctic Ocean has rapidly lost its summer sea-ice cover. The sea ice area has decreased by 3-4\% every decade, while in summer, it has decreased by 7-9\% [15-17]. Comiso [18] et al. (2008) compared and analyzed the decline rate of Arctic sea ice in two periods before and after 1997, and found that the decline rate of sea ice increased from 2.2\% per decade before 1997 to $10.1 \%$ per decade after 1997. Stroeve [19] et al. (2012) further confirmed the trend of accelerated decline of Arctic sea ice extent. Different sea ice conditions will affect the heat flux exchange between the ocean and the atmosphere, causing changes in the local atmospheric circulation, and these changes will further affect the ocean process. There is evidence of increasing heat entering the Arctic Ocean through the Bering Strait during summer [20], and the upper ocean in the Arctic has warmed to unprecedented levels, including the shallow Chukchi Sea [21]. Model simulations indicate that in most areas, the main driver of seasonal ocean surface warming are downward atmospheric heat fluxes; some inflow areas like the Chukchi Sea warm up through ocean advection [22]. Since late 1990s, the Arctic has been warming more than twice as rapidly as the global average [23,24]. Steele et al. [25] reported that surface warming in the Arctic Ocean (since 1965) has been particularly pronounced since 1995. The retreating sea ice and warming environment may lead to significant oceanic changes, particularly in the marginal seas, where the edge of the sea ice is located. The decrease of sea ice will strengthen the upwelling near the Chukchi slope [26], thereby bringing the warm Atlantic water from deep basin to the shelf and affecting water properties there.

Despite the studies to date, further work is required to better understand the specific changes in the Chukchi Sea where the retreat of sea ice has accelerated recently. The rapid retreat of sea ice results in more melt water and a longer exposure of the sea surface to surface heating and wind stress; thereby significantly modifying the water mass characteristics, stratification, and vertical mixing of the water column. In this study, we use available hydrographic data to investigate the oceanic changes in the eastern Chukchi Sea with a focus on the water mass characteristics and vertical thermohaline structures. We make a comparison between two periods: pre-1997 and post-1997, and attempt to reveal the unique responses in different regions of the Chukchi Sea.

The structure of the paper is as follows: In Section 2, datasets are described. In Section 3, results are presented about the summer hydrography of the Chukchi Sea and oceanic changes surrounding the 1997 regime shift. Finally, Section 4 provides a discussion and conclusions.

\section{Data and Methods}

The ocean temperature and salinity data of the region $175^{\circ} \mathrm{E}-155^{\circ} \mathrm{W}, 60^{\circ}-75^{\circ} \mathrm{N}$ are obtained from the World Ocean Database (WOD13) at the National Oceanographic Data Centre (https://www. nodc.noaa.gov), which contains the high-resolution conductivity-temperature-depth (CTD) data from 1974 to 2017 . The dataset provides the temperature and salinity data with a high level of quality control, including all preliminary and automatic quality control checks (i.e., minimum/maximum range assessment) [27]. An additional data source is the Chinese National Arctic Research Expedition (CNARE), which includes the observations from cruises conducted in 1999, 2003, 2008, 2010, and 2014 
(http://www.chinare.org.cn). The hydrographic measurements from CNARE were collected using MarkIIIC and Sea-Bird SBE 9 CTD. After the removal of profiles that were positioned over land, wrong or empty stations, 10,518 profiles remain for the summer months (July, August, and September). The observation data do not cover all years. The time series of the number of stations counted by each year is shown in Figure 1a, and the distribution of all profiles in the study domain is shown in Figure 1b; the purple dots represent the stations from 1974 to 1997 , and the yellow dots represent the stations from 1998 to 2017. In this paper, we used potential temperature and salinity to study water mass characteristics and hydrographic features.

(a)

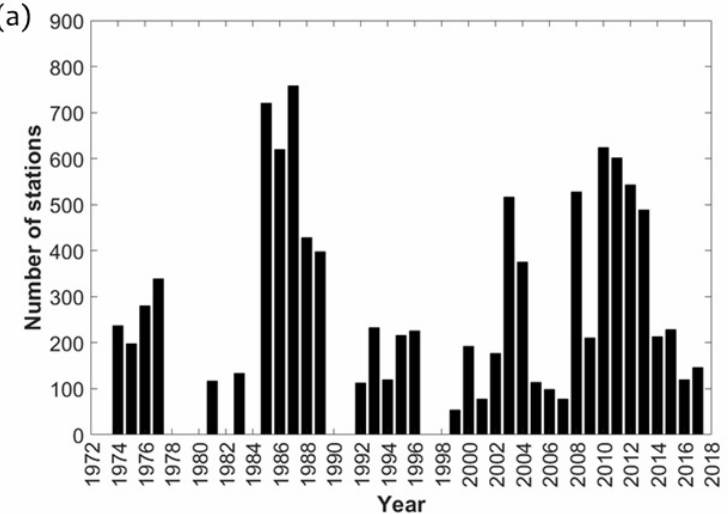

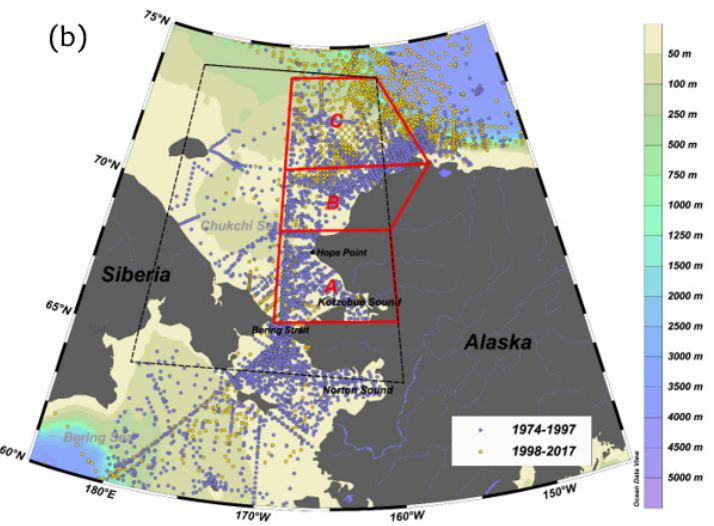

Figure 1. (a) Temporal distribution of the number of observation stations per year from 1974 to 2017 based on WOD13 and CNARE. (b) Distributions of all available T and S profiles in the study region; purple dots represent observations during 1974-1997, and yellow dots represent observations during 1998-2017; black dashed box represents the area for the T-S diagram; red boxes marked by A $\left(66^{\circ}-69^{\circ} \mathrm{N}\right.$, $\left.170^{\circ}-160^{\circ} \mathrm{W}\right), \mathrm{B}\left(69^{\circ}-71^{\circ} \mathrm{N}, 170^{\circ}-165^{\circ} \mathrm{W}\right)$ and $\mathrm{C}\left(71^{\circ}-74^{\circ} \mathrm{N}, 170^{\circ}-160^{\circ} \mathrm{W}\right)$ represent the three study subregions in Section 3.3.3.

The data of monthly mean surface net heat flux are provided by Woods Hole Oceanographic Institution (WHOI) OA Air-Sea Fluxes (OAFlux, http://oaflux.whoi.edu/descriptionheatflux.html). The net heat flux Qnet (positive downward, 1-degree grid) is computed as Qnet $=\mathrm{SW}-\mathrm{LW}-\mathrm{SH}$ - LH, where SW denotes the net downward shortwave radiation, LW the net upward longwave radiation, $\mathrm{SH}$ the upward sensible heat flux, and LH the upward latent heat flux. The sea ice extent and concentration data are based on passive microwave remote sensing instruments, and the data are obtained from the National Snow and Ice Data Center (NSIDC) (https://nsidc.org/data/).

The scattered profile data are gridded to a regular grid with mapping scales of $0.5^{\circ}$ in both latitude and longitude. A linear interpolation function provided in MATLAB was used to interpolate the scattered data (more detailed information is provided by the reference page: https://ww2.mathworks. $\mathrm{cn} /$ help/matlab/ref/gridfit.html). Because many profiles of the surface layer are not sufficiently accurate, the sea surface temperature (SST) and sea surface salinity (SSS) were defined as the mean temperature and salinity over the upper $10 \mathrm{~m}$. In this study, the trends are obtained using the linear regression analysis. Statistical significance is based on the $p$-value (i.e., the probability of observing the given result) of the F statistic. The F statistic is a test statistic of the F-test on the regression model, for a significantly linear regression relationship between the response variable and the predictor variables. To determine the statistical significance between means of two samples, the Student's t-test was used in difference maps. Our null hypothesis is that the two samples are statistically indistinguishable from each other. The null hypothesis is rejected if the value exceeds the $95 \%$ confidence interval.

Because of the complicated physical processes and topography, the Chukchi Sea exhibits several regions with different water characteristics. In our study, the eastern Chukchi shelf was divided into three subregions (marked in Figure $1 \mathrm{~b})$ : (A) southern $\left(66^{\circ}-69^{\circ} \mathrm{N}, 170^{\circ}-160^{\circ} \mathrm{W}\right),(\mathrm{B})$ central $\left(69^{\circ}-71^{\circ} \mathrm{N}\right.$, $\left.170^{\circ}-165^{\circ} \mathrm{W}\right)$, and $(\mathrm{C})$ northern $\left(71^{\circ}-74^{\circ} \mathrm{N}, 170^{\circ}-160^{\circ} \mathrm{W}\right)$ Chukchi Sea. 


\section{Results}

\subsection{Hydrography during Summer: Spatial Distribution of Water Masses}

The T-S diagram for all available hydrographic data in the study domain are shown in Figure 2, colored by the latitudes of the observations. The two mixed water masses, BSW and CSW, occupy the lower and higher latitudes, respectively. The SMW has a large range of temperatures depending on the season. Following previous study [28], we distinguish between newly melted water (early_SMW; with temperatures approaching the freezing point) and old melted water (late_SMW, with temperatures far above the freezing point). The PSW is comprised of ACW, BSW and CSW.

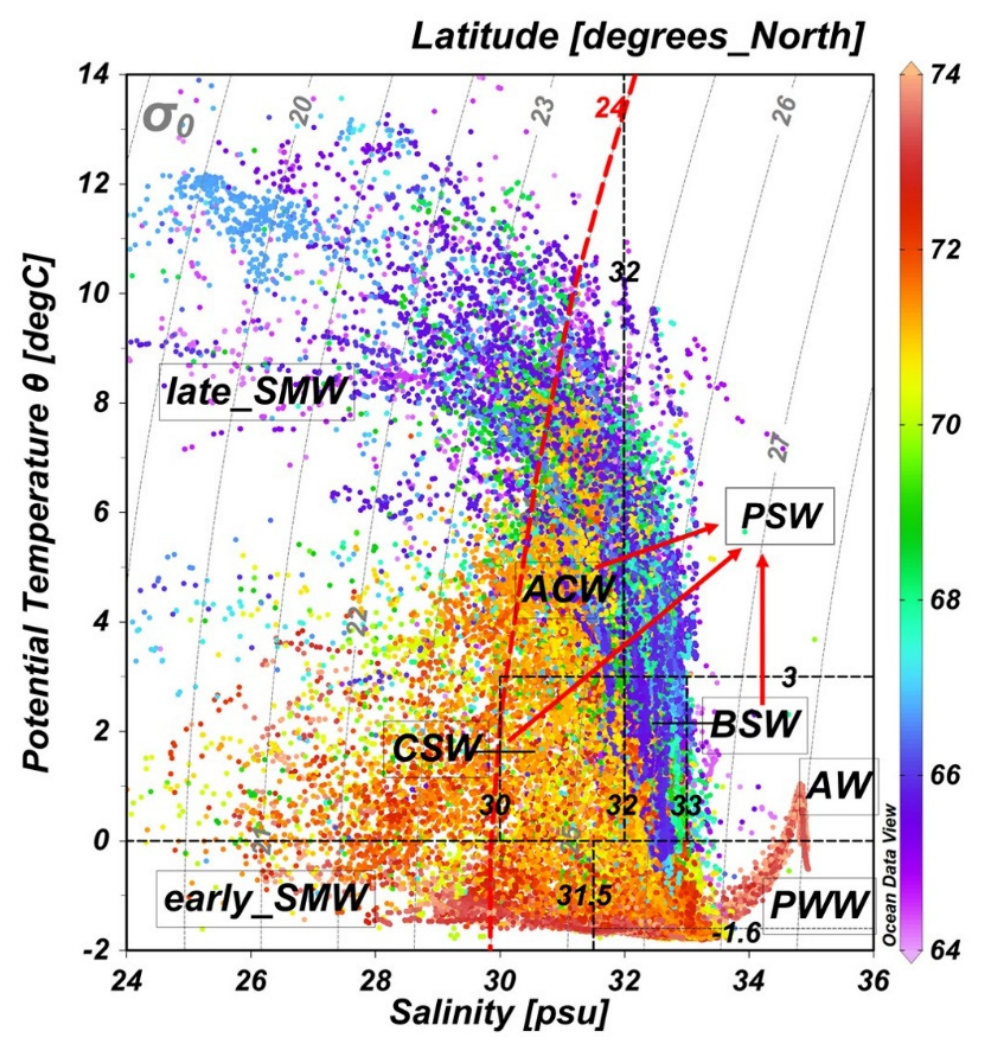

Figure 2. T-S plot of CTD data for the Chukchi Sea from July to September; dot colors represent the latitudes of the observations, and potential density contours are superimposed; major water masses are marked by dashed and red lines, and black numbers indicate the water mass boundaries. AW: Atlantic Water; ACW: Alaskan Coastal Water; BSW: Bering Summer Water; CSW: Chukchi Summer Water; SMW: Seasonal Melt Water; PWW: Pacific Winter Water. PSW: Pacific Summer Water, which includes ACW, BSW and CSW.

Figure 3a-d shows the maps of shelf-wide distributions of the long-term (1974-2017) summer mean surface temperature and salinity. During summer, warmer $\left(\mathrm{T}>3^{\circ} \mathrm{C}\right)$ and saltier $(\mathrm{S}>30)$ surface PSW occupies approximately the entire Chukchi shelf, and colder $\left(\mathrm{T}<3{ }^{\circ} \mathrm{C}\right)$ and fresher $(\mathrm{S}<30)$ melting water exists in the north of the shelf edge (100 $\mathrm{m}$ isobaths). There are two relatively cold areas over the Chukchi shelf; one extends along the east Siberian coast because of the cold East Siberian Current that flows southward, and the other extends over the Herald Shoal, which results from a Taylor column that traps ice and cold water above the shoal and therefore results in ice melting that is later than that in the surrounding water [29]. The warmest ACW flows through the eastern channel of the Bering Strait and continues to flow along the Alaskan coast. The ACW has two branches owing to the bifurcation of the coastal current [10,30,31]. One flows north-eastward along the Alaskan coast to the Barrow Canyon; the other extends offshore from the Alaskan coast near Point Hope toward the northwest, which clearly manifests as a northwest-extending warm tongue; subsequently, the warm 
water flows eastward along the northern part of the Herald Shoal. The distribution of the surface water properties clearly reflects the surface circulation pattern (see Figure 1 in Corlett and Pickart [32]). The bottom water is less influenced by the local air-sea fluxes; thus, it usually keeps its original water properties. The north edge of the PSW is located approximately $72^{\circ} \mathrm{N}$, approximately along $50 \mathrm{~m}$ isobaths; north of the PSW is the PWW, which occupies the northeastern Chukchi shelf and slope (Figure 3b).
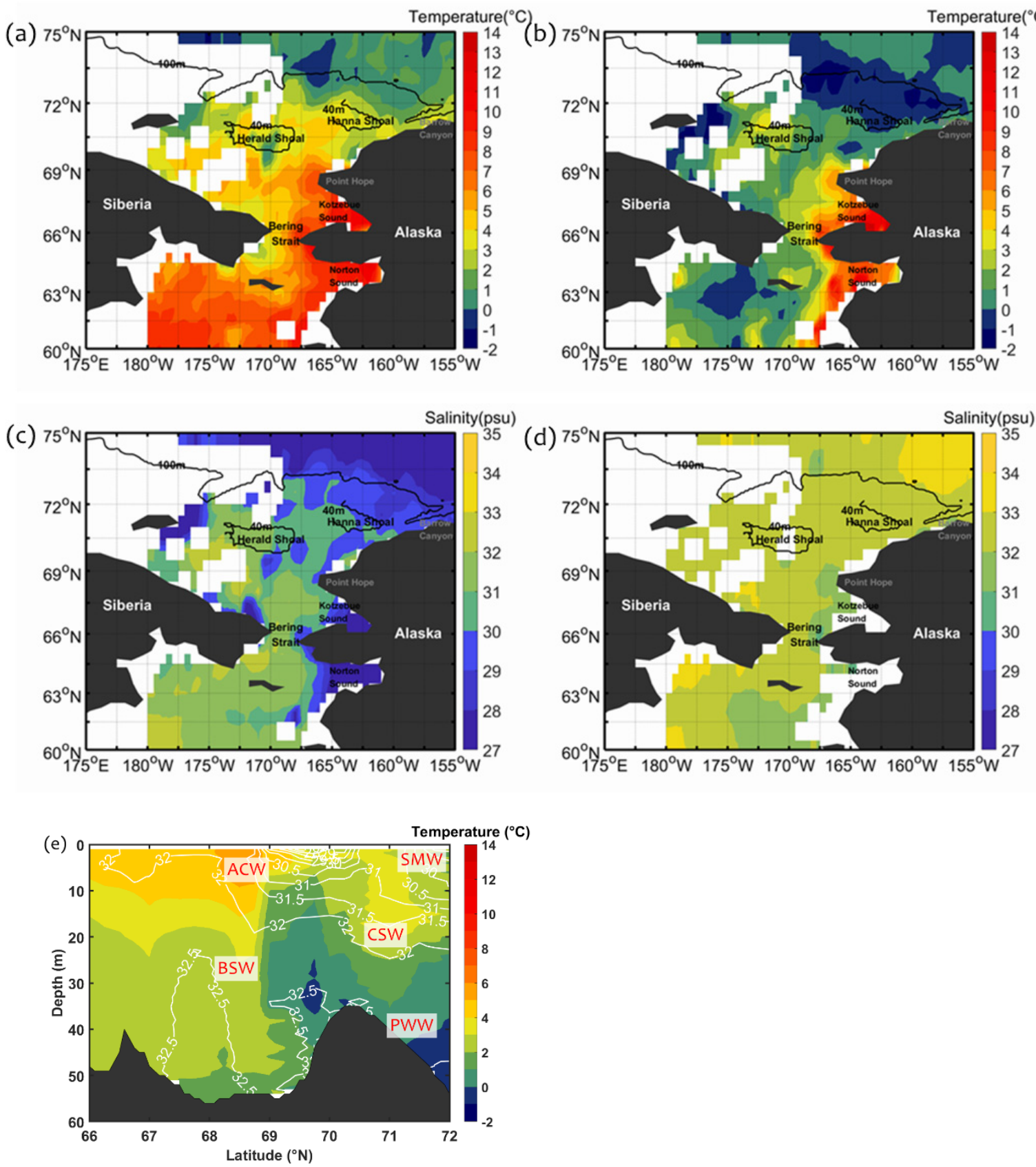

Figure 3. Long-term mean (a) surface and (b) bottom temperature, (c) surface and (d) bottom salinity according to available data of the summer seasons from 1974 to 2017; (e) vertical section of temperature (shaded) and salinity (white contour) along $169^{\circ} \mathrm{W}$. The solid black contours in panels a-d represent the $100 \mathrm{~m}$ and $40 \mathrm{~m}$ isobaths.

The vertical distribution of water masses is reflected by a section in the central channel in $169^{\circ} \mathrm{W}$ direction (Figure 3e). Along the central channel, the north limit of the ACW is located at approximately 
$69^{\circ} \mathrm{N}$ owing to the bifurcation of the ACC. The bifurcation provides a barrier, which limits the effects of the Pacific inflows on the northern part of the section; thus, the PWW is not flushed away by the PSW. South of $69^{\circ} \mathrm{N}$, the warmest ACW occupies the upper layer, and the BSW resides in the deep layer. North of $69^{\circ} \mathrm{N}$, the water column consists of three water masses: the SMW in the surface, PWW in the bottom, and CSW in the middle layers. The approximate location of each water mass is marked in Figure $3 e$.

\subsection{Temporal Changes in Temperature and Salinity}

The standard deviation of the summer mean surface temperature from 1974 to 2017 displays high values in the central and northern Chukchi Sea (north of $69^{\circ} \mathrm{N}$ ) and low values in the south (Figure 4). The distribution of the centers of the local maximums coincides with the ACW pathway, and the high values across the northern Chukchi shelf are in accordance with the evident interannual variability of the ice cover. By contrast, the southern Chukchi Sea is usually ice-free during summer and is significantly influenced by the relatively steady Pacific inflow. Based on the features of the standard deviation of the surface temperature, the long-term changes in the temperature and salinity in the southern, central, and northern Chukchi Sea are studied.

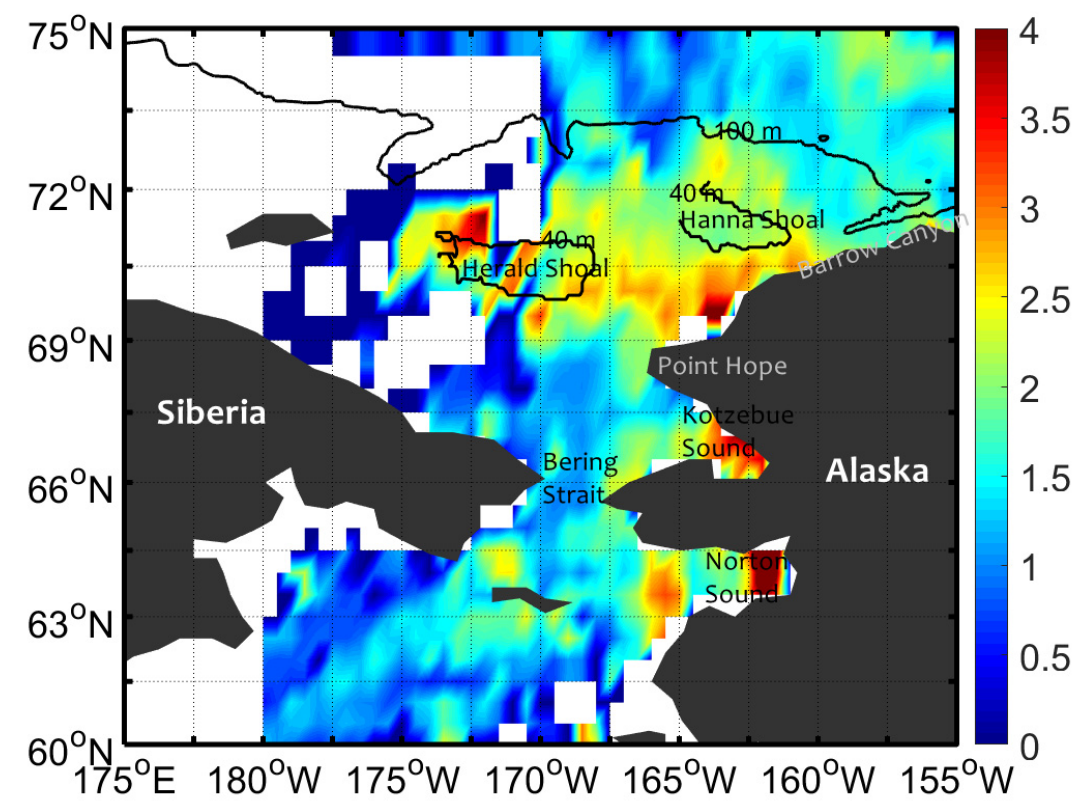

Figure 4. Standard deviation (shaded) of summer mean surface temperature from 1974 to 2017.

The solid black contours represent $100 \mathrm{~m}$ and $40 \mathrm{~m}$ isobaths.

Figure 5 shows the time series of the average temperature $(T)$ and salinity $(S)$ of the entire water column for the three regions. The trends of $\mathrm{T}$ and $\mathrm{S}$ are statistically not-significant in the southern and northern Chukchi Sea. But, in the central shelf, the warming trend is significant and the temperature increase is approximately $0.56{ }^{\circ} \mathrm{C} /$ decade; thus, the water temperature has increased by more than $2.0^{\circ} \mathrm{C}$ in 40 years. The salinity of the whole water column in the central Chukchi Sea, however, has not shown any significant changes during the past 40 years. Table 1 lists the trends and their $p$-values, and the values in bold represent the corresponding trends with confidence levels above $95 \%$. 
(a)

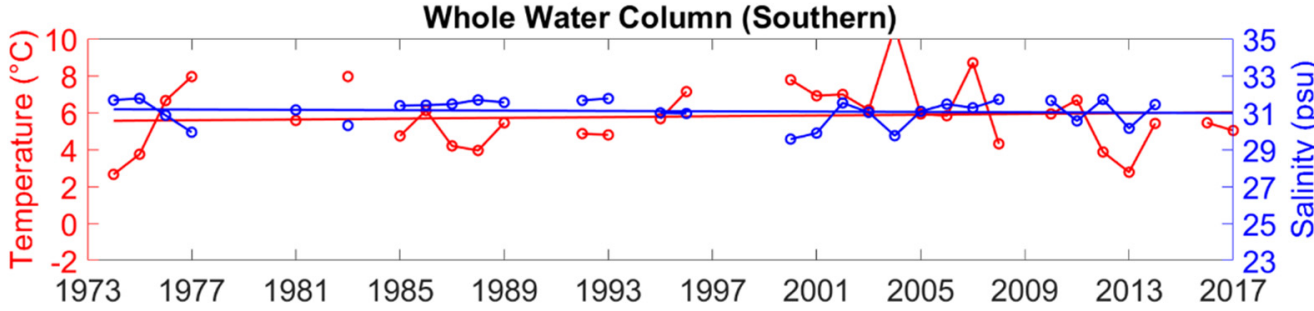

(b)

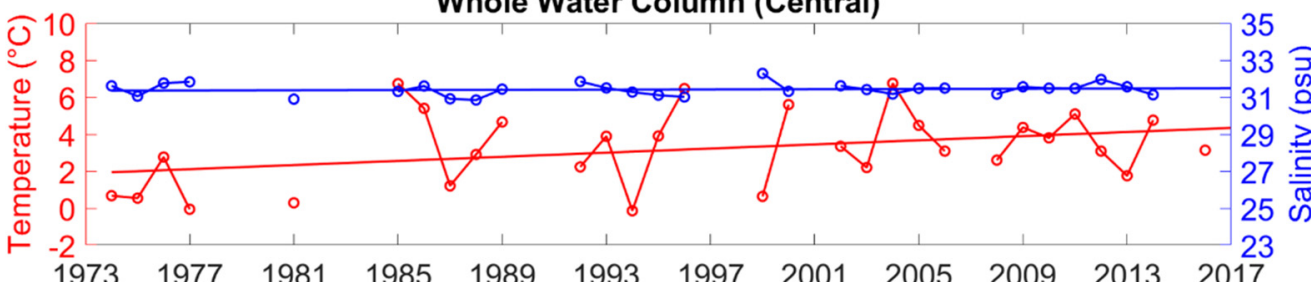

(c)

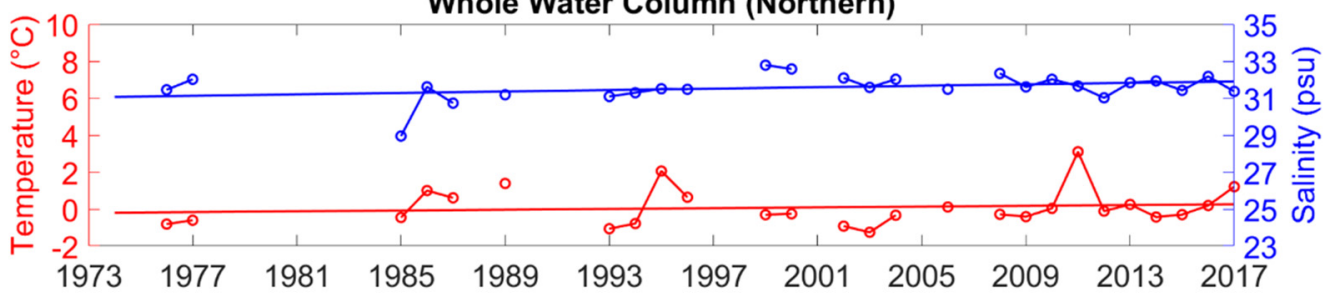

Figure 5. Time series for the entire water column in the (a) southern, (b) central, and (c) northern Chukchi Sea.

Table 1. The trends $\left({ }^{\circ} \mathrm{C} \cdot\right.$ year $^{-1}$ for temperature (T); $\operatorname{psu~year~}^{-1}$ for salinity (S)) and their $p$-values of the temperature and salinity of the whole water column, surface and bottom in the southern, central and northern Chukchi Sea. The values in bold represent the corresponding trends with confidence levels above $95 \%$.

\begin{tabular}{|c|c|c|c|}
\hline & Southern & Central & Northern \\
\hline & & ole Water Column & \\
\hline $\mathbf{T}$ & $0.0107(0.6609)$ & $0.0558(0.0476)$ & $0.0106(0.5354)$ \\
\hline $\mathrm{S}$ & $-0.0047(0.6533)$ & $\begin{array}{l}0.0030(0.5751) \\
\text { Surface }\end{array}$ & $0.0194(0.1053)$ \\
\hline $\mathbf{T}$ & $0.0135(0.5253)$ & $0.0668(0.0254)$ & $0.0340(0.1319)$ \\
\hline $\mathrm{S}$ & $0.0049(0.6268)$ & $\begin{array}{l}0.0229(0.0140) \\
\text { Bottom }\end{array}$ & $0.0355(0.1549)$ \\
\hline $\mathbf{T}$ & $0.0313(0.1935)$ & $0.0356(0.2324)$ & $0.0152(0.1590)$ \\
\hline $\mathrm{S}$ & $-0.0204(0.0483)$ & $-0.0156(0.0129)$ & $-0.0045(0.5036)$ \\
\hline
\end{tabular}

To further our understanding of the long-term hydrography changes, the similar calculation has been done for the surface and bottom layers, the results are listed in Table 1. The central shelf has the most significant changes in both temperature and salinity. The linear trends of surface temperature and surface salinity in the central shelf are $+0.67{ }^{\circ} \mathrm{C} /$ decade and $+0.23 \mathrm{psu} / \mathrm{decade}$, respectively. While the trends in the bottom temperature are less evident than those of the surface layer, the bottom salinity in the central shelf has a negative trend of $-0.16 \mathrm{psu} /$ decade. The opposite trends in surface and bottom layer salinity leads to a statistically not-significant trend for the whole water column in the central shelf as mentioned above. The opposite trends also imply that the vertical structure of the salinity has changed. In the southern and northern shelf, surface warming and salinification are not significant. Bottom salinity of the southern shelf decreases with a significant negative trend of -0.20 $\mathrm{psu} /$ decade, probably because of the enhanced transport of the fresher Pacific inflow. 


\subsection{Oceanic Regime Shifts around 1997}

In recent decades, the Arctic has experienced dramatic changes, including changes in the atmosphere, sea ice and sea water. The downward domain-averaged net surface heat flux (NSHF) indicates the Chukchi Sea absorbs heat in summer. Although the trend over the whole period is increasing, it is clearly seen from Figure 6a that the NSHF has a different trend in the two periods before and after around 1997. The NSHF was decreasing during 1983-1997, with a negative trend of $-1.1 \mathrm{~W} / \mathrm{m}^{2} /$ year. But, a significant increase started after 1997 , with a positive trend of $0.7 \mathrm{~W} / \mathrm{m}^{2} /$ year, leading to a significantly warmer surface in the summer Chukchi Sea after 1997 that impacts the atmosphere-ice-sea interaction. The net shortwave radiation contributes the most to the trend shift (Figure 6b).

(a)

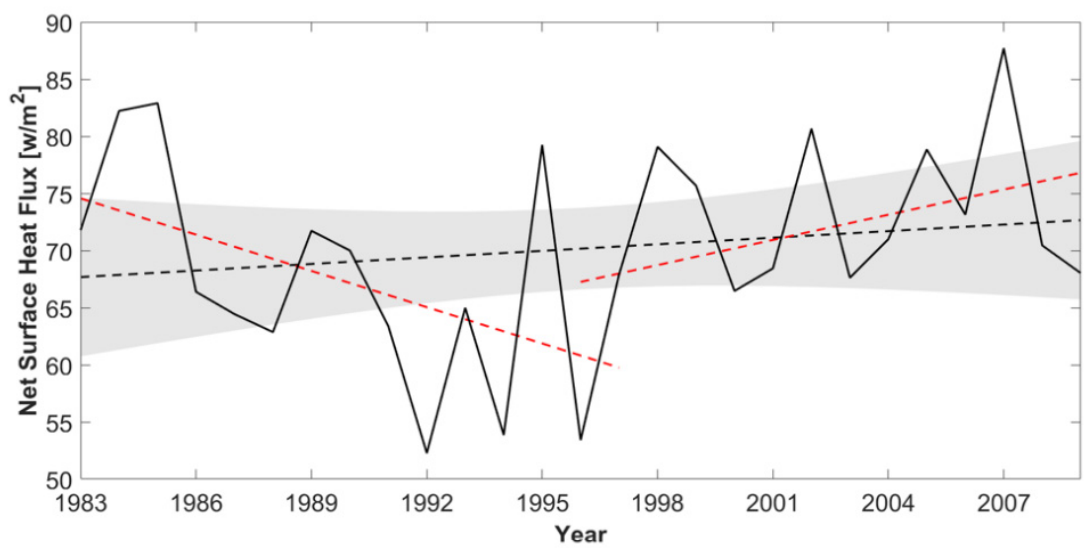

(b)

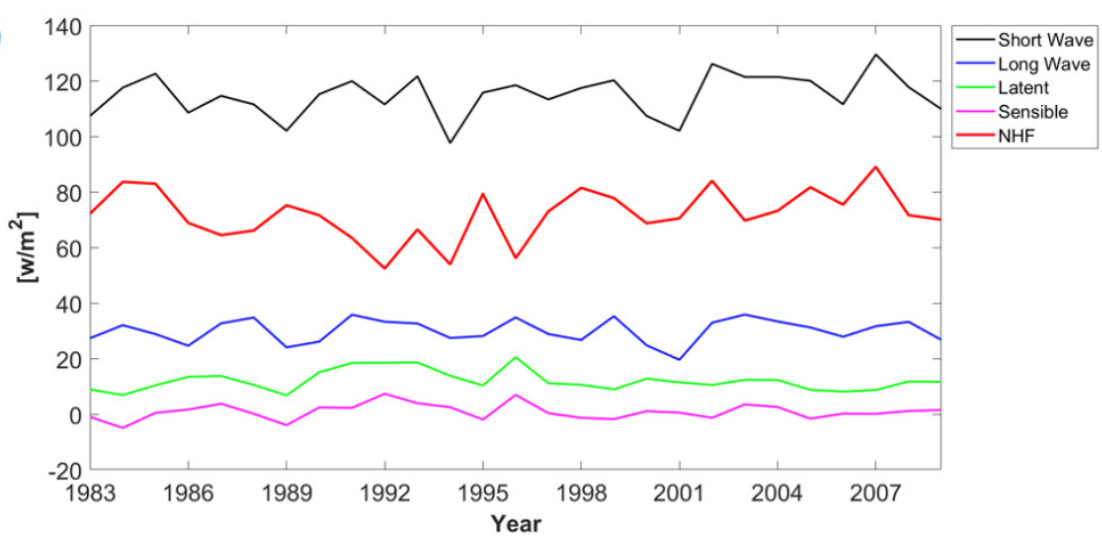

Figure 6. (a) Time series of net surface heat flux (NSHF) in the Chukchi Sea during summer from 1983 to 2009. The dash lines are trends of the whole (black line), pre- and post-1997 (red lines) periods. The gray shading indicates the two-sided 95\% confidence boundary. (b) Time series of NHF (red line), net short-wave radiation (black line), net long-wave radiation (blue line), latent heat flux (green line) and sensible heat flux (magenta line).

The long-term changes in sea-ice extent further confirm the regime shift around 1997. Figure 7 shows the sea-ice extent anomaly since 1978, with significant trends at the two-sided 95\% confidence level, indicating the decrease in the sea-ice extent accelerated after late 1990s (around 1997). The diminishing sea-ice cover and ice thickness affect advection and fresh water flux in the Chukchi Sea. To characterize the oceanic changes of the 1997 regime shift, the hydrographic dataset was classified into pre- and post-1997 periods in the subsequent research (1997 is included in the former period). 


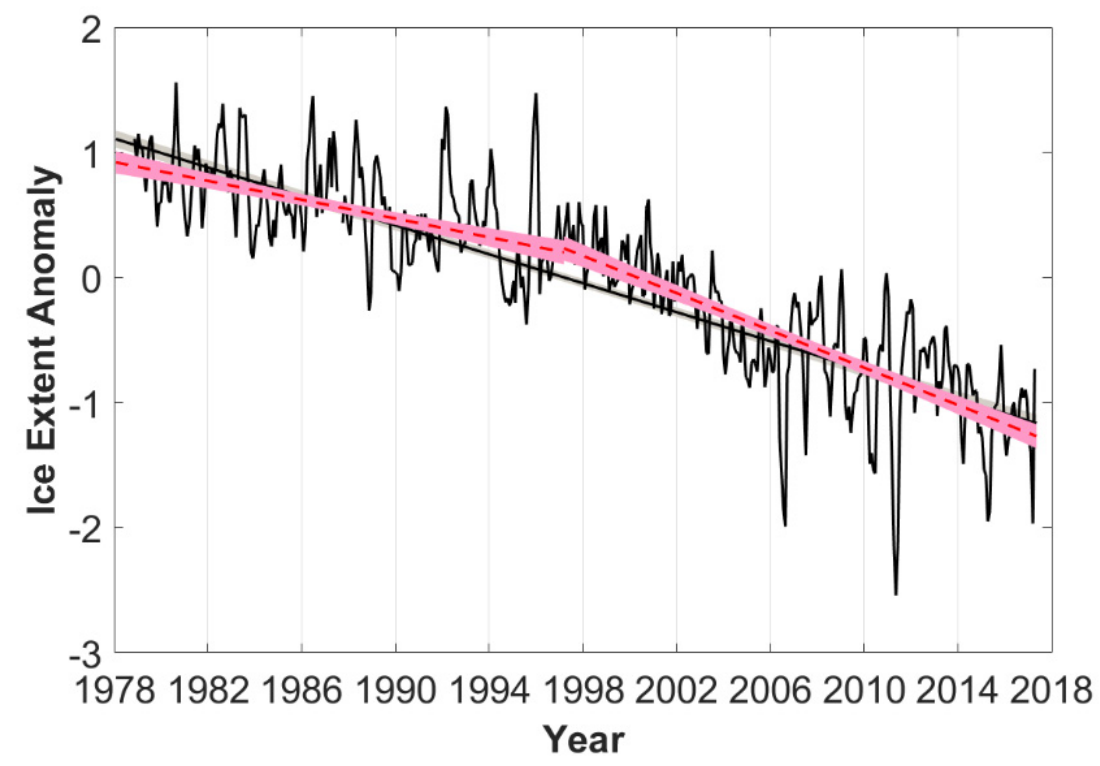

Figure 7. Time series of monthly sea-ice extent anomaly in the Arctic from 1979 to 2017. The gray and red shadings indicate the two-sided $95 \%$ confidence boundary.

Considering regional differences in the Chukchi Sea, daily evolutions of the area-averaged ice cover in the three subregions mentioned above are plotted in Figure 8. The southern Chukchi Sea experienced a similar ice-melting time in pre- and post-1997. In the central, the daily evolution shows that the ice-free date ranged from the 210th to 280th day of the year after 1997, which was approximately 50-60 days longer than before 1997. In the north, the ice-free season was prolongated after 1997. The change of the ice-melting time in the Chukchi Sea will affect the surface forcing; leading to hydrographic changes that will be presented and discussed in the following.
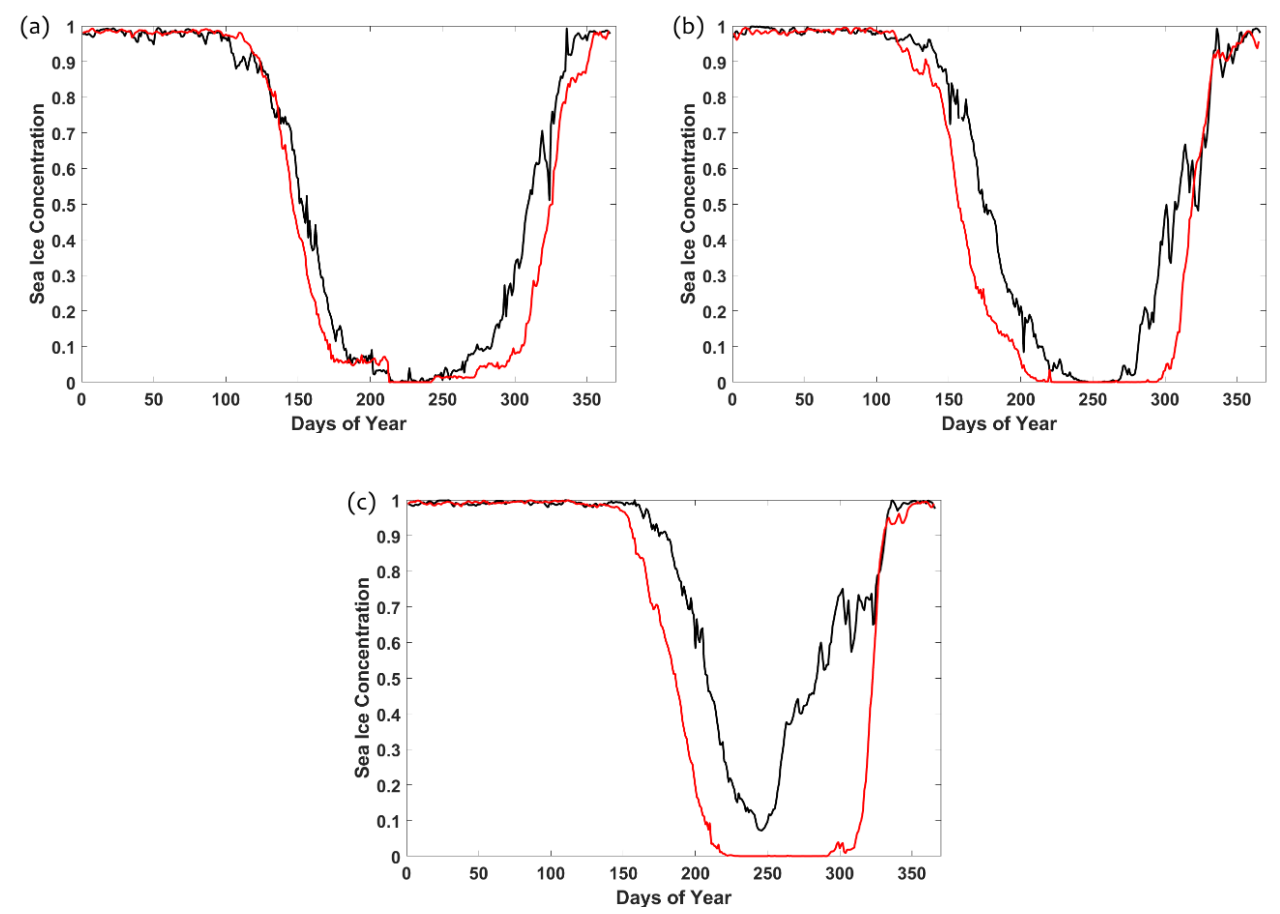

Figure 8. Daily evolutions of the area-averaged ice cover in (a) southern, (b) central and (c) northern Chukchi Sea; black curves represent multi-year mean data from the pre-1997 period, while red contours represent the post-1997 period. 


\subsubsection{Changes in Water Mass Characteristics}

The T-S diagrams of the southern, central, and northern shelves of the two periods are shown in Figure 9; the light blue and yellow dots represent the pre- and post-1997 periods, and the blue and red triangles represent the mean values of the water masses, respectively.
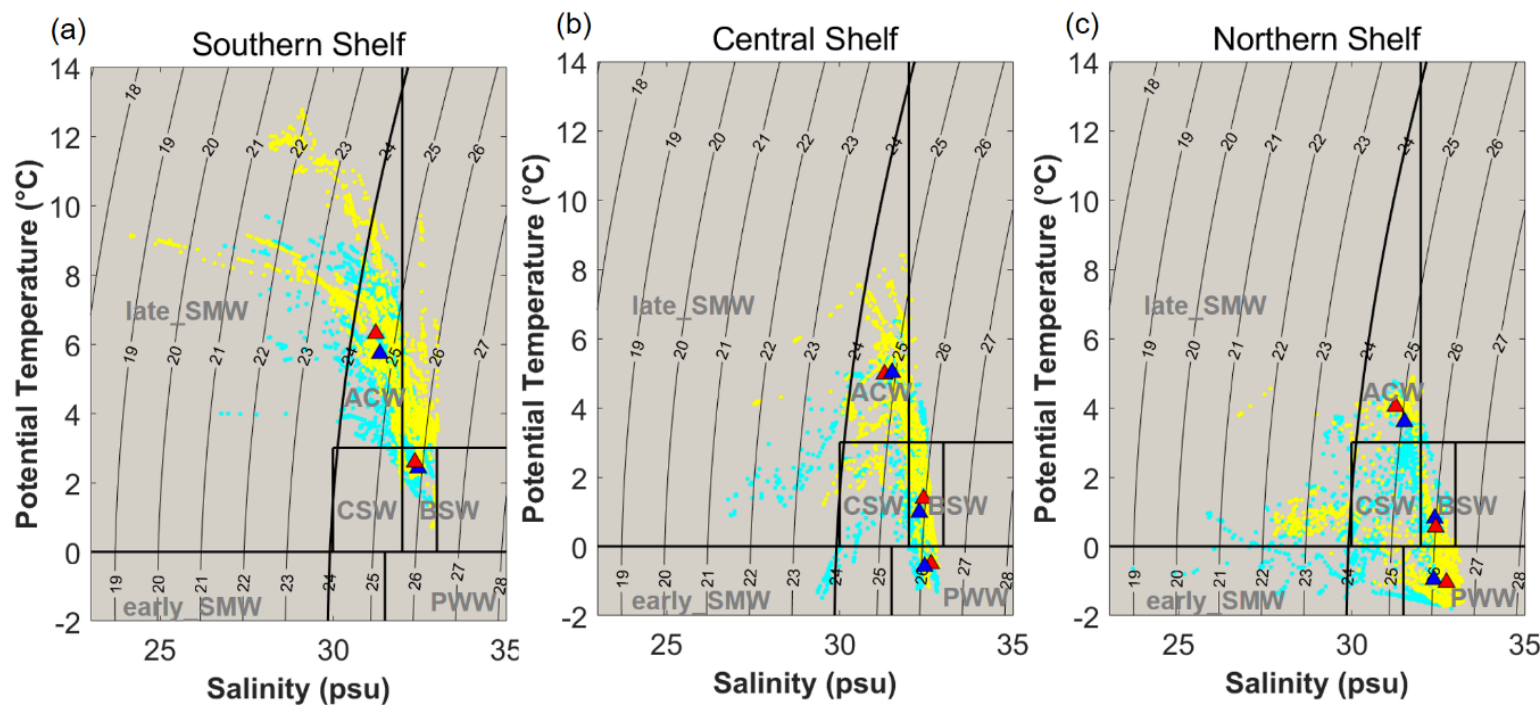

Figure 9. T-S diagrams of (a) southern, (b) central and (c) northern shelf. The light blue and yellow dots belong to the pre- and post-1997 periods, respectively; blue and red solid triangles denote the mean values of the water masses of the pre- and post-1997 periods, respectively.

The ACW and BSW dominated the southern Chukchi Sea during both periods (Figure 9a). A comparison between the post- and pre-1997 data reveals that the sea water warmed up after 1997. Moreover, Figure 9a exhibits a cluster of observations with water temperatures above $3^{\circ} \mathrm{C}$ and salinity above 32 psu after 1997. The salinity and density of the water mass are similar to those of the BSW. Although the water temperature is higher than that in the previous definition of the BSW, this water mass can be still classified as "BSW." Hence, the previous BSW definition should be modified to include the recently warmer water.

The main water masses over the central Chukchi shelf includes ACW, BSW, CSW, and PWW (Figure 9b). The T-S diagram shows that the quantity of BSW increased after 1997, and the PWW had a higher quantity in pre-1997 than in post-1997; only little PWW was left in this area after 1997. The mean temperature of the BSW post-1997 was higher than before, while the salinity exhibited a slight increase. Moreover, the temperature of the ACW in this area changed insignificantly.

On the northern Chukchi shelf, PWW occupied a considerable portion of the observations in both periods. The salinity and density of the PWW increased remarkably after 1997 (Figure 9c). The reason for the salinity increase is still unclear; a possible cause could be the increase in the formation of polynyas over the past few decades [33], thereby leading to denser water.

\subsubsection{Changes in Summer Hydrography}

The warm PSW in the surface layer $\left(\mathrm{T}>3-4{ }^{\circ} \mathrm{C}\right)$ extended further north after 1997; its edge was located at approximately $72^{\circ} \mathrm{N}$, and approximately along $50 \mathrm{~m}$ isobaths (Figure 10a-d), whereas it was located at approximately $70^{\circ} \mathrm{N}$ before 1997 . North of the warm water lies the melting water. The extension of the PSW has led to a significant warming and salting in the east of the Herald Shoal after 1997 (Figure 10e,f) because the salt and warm PSW replaces the fresh and cold melting water. The SST and SSS differences also show another remarkable warming and salinification phenomenon west of Point Hope, which may be due to the effect of the ACW. Only values passing the T-test (confidence levels: 95\%) are shown in these difference maps (same in Figures 11 and 12). 
(a)

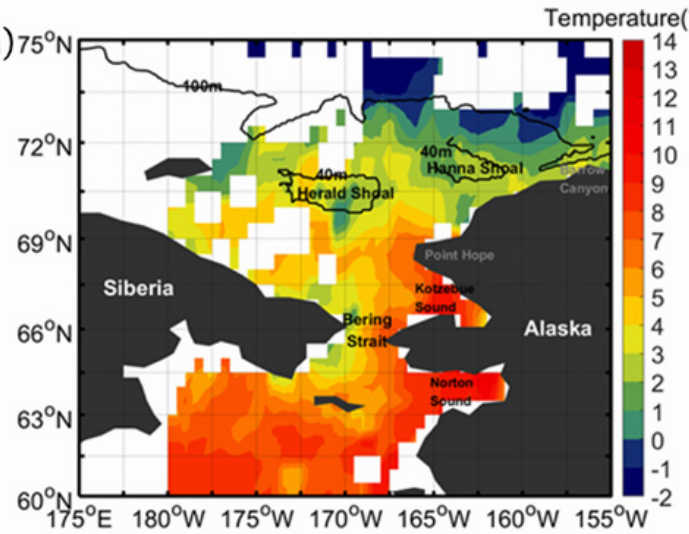

(c)

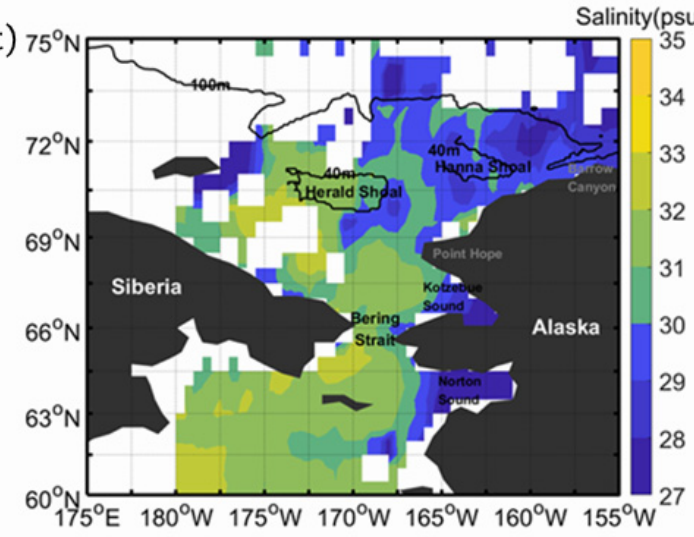

(e) $75^{\circ}$

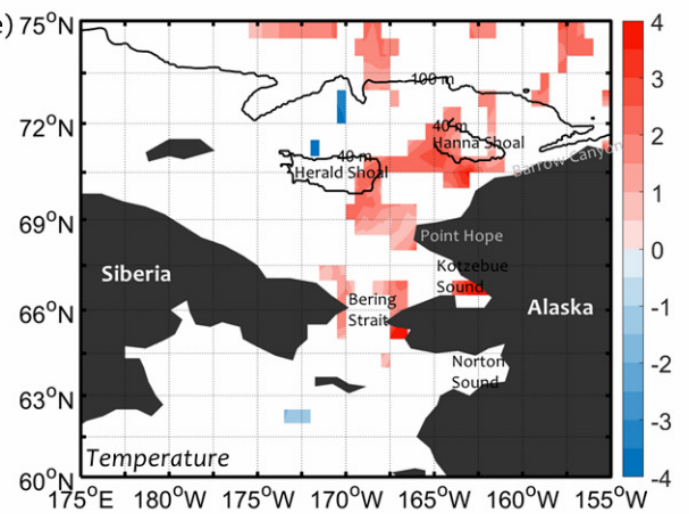

(b)

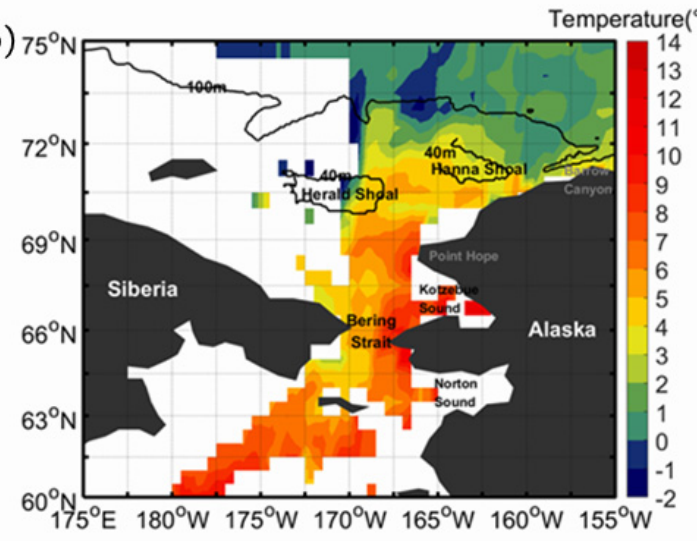

(d)

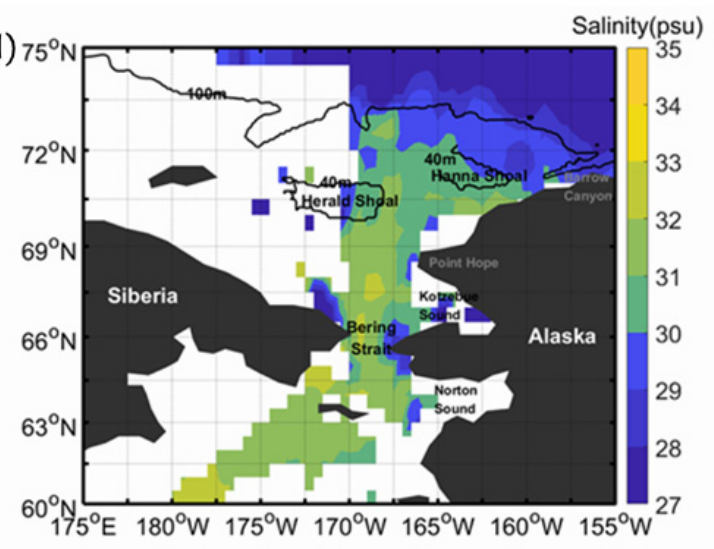

Figure 10. Surface temperature of (a) pre-1997 and (b) post-1997 periods, and (c,d) for salinity; differences in (e) surface temperature and (f) surface salinity between the two periods. The solid black contours represent $100 \mathrm{~m}$ and $40 \mathrm{~m}$ isobaths.

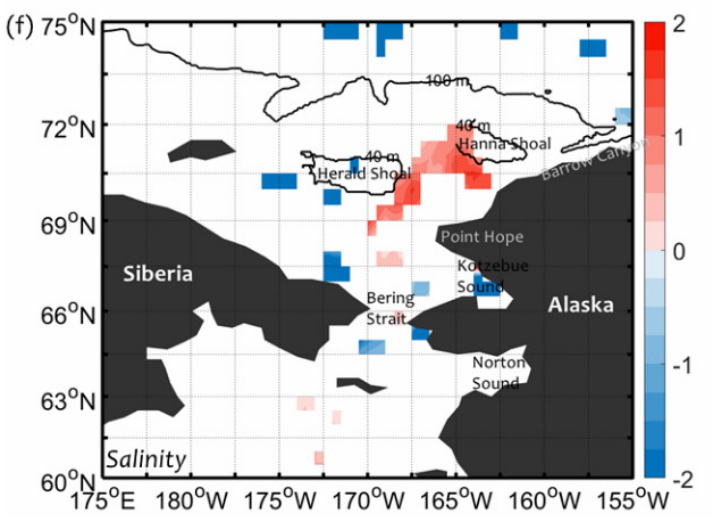


(a)

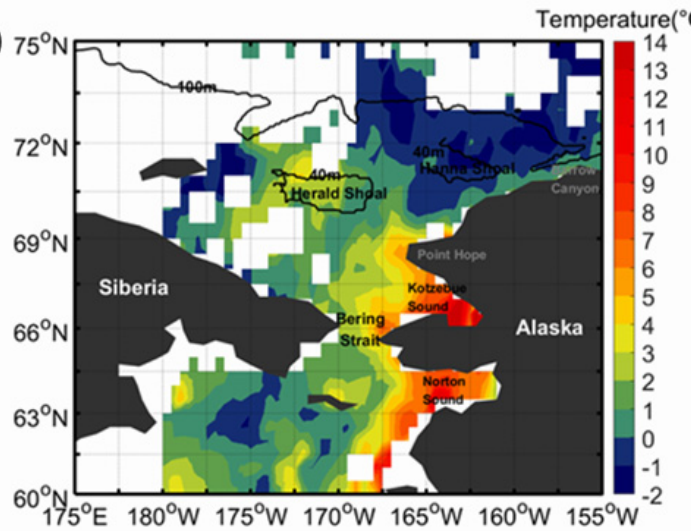

(c)

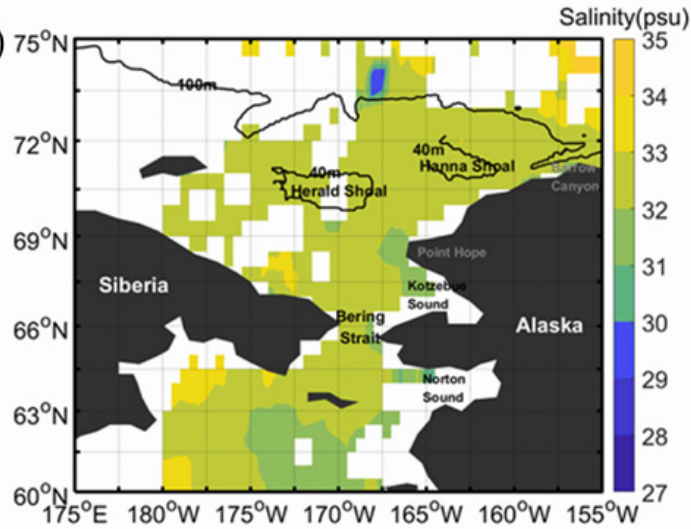

(e) $75^{\circ} \mathrm{N}$

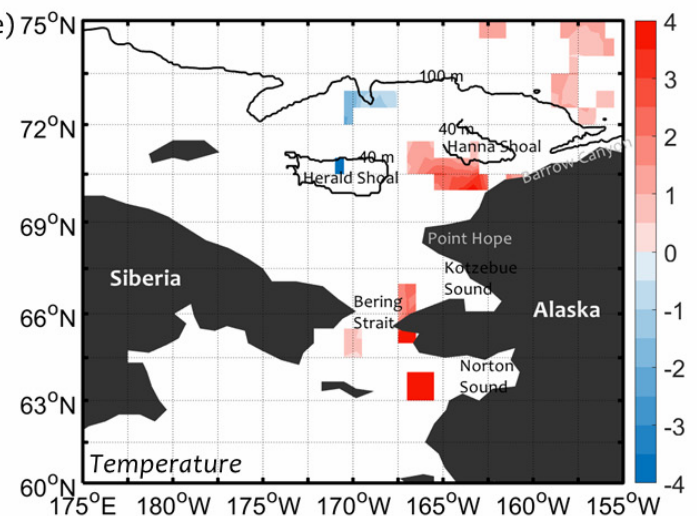

Temperature $\left.{ }^{\circ} \mathrm{C}\right)$

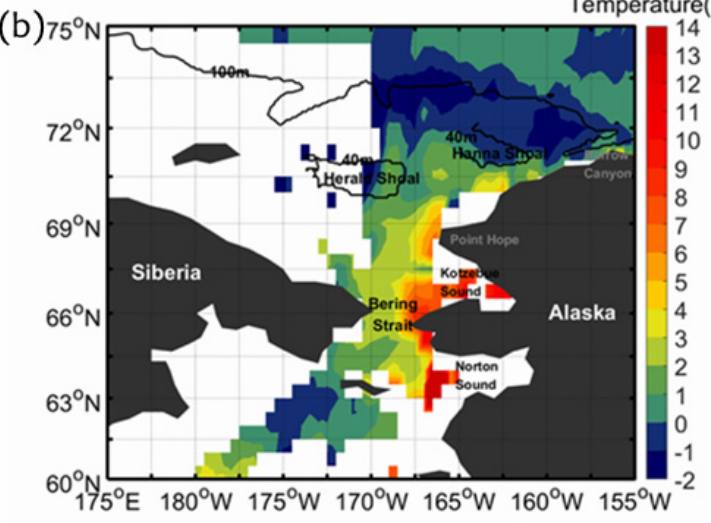

(d)

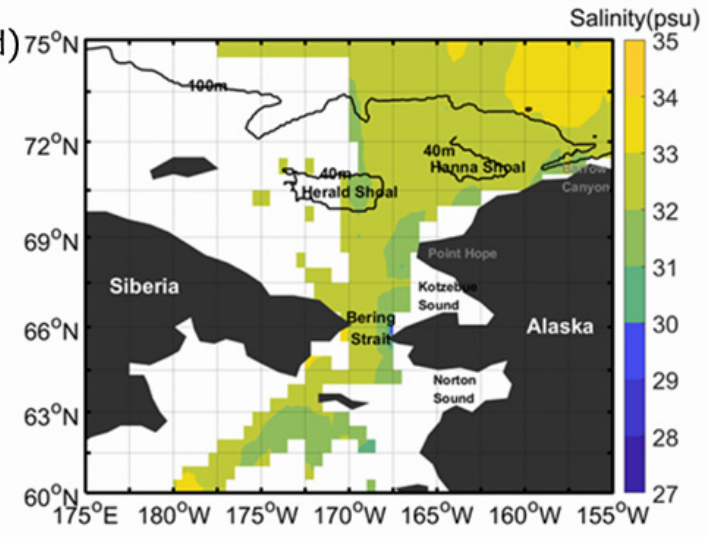

(f) 75

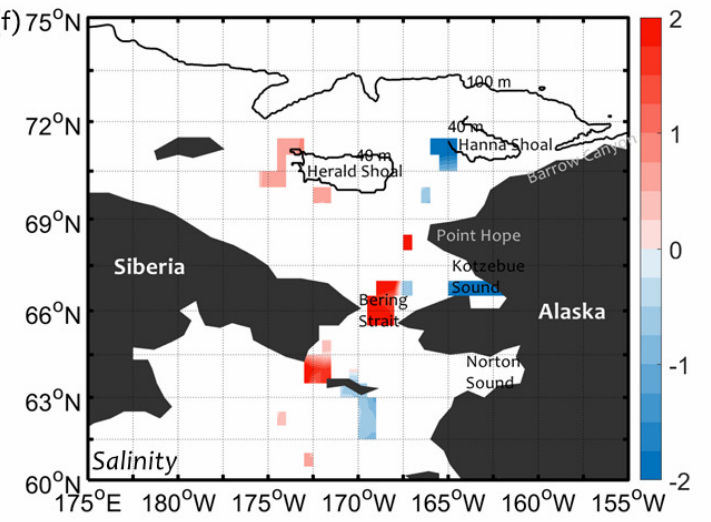

Figure 11. Bottom temperature of (a) pre-1997 and (b) post-1997 periods, and (c,d) for salinity; differences in (e) bottom temperature and (f) bottom salinity between the two periods. The solid black contours represent $100 \mathrm{~m}$ and $40 \mathrm{~m}$ isobaths. 

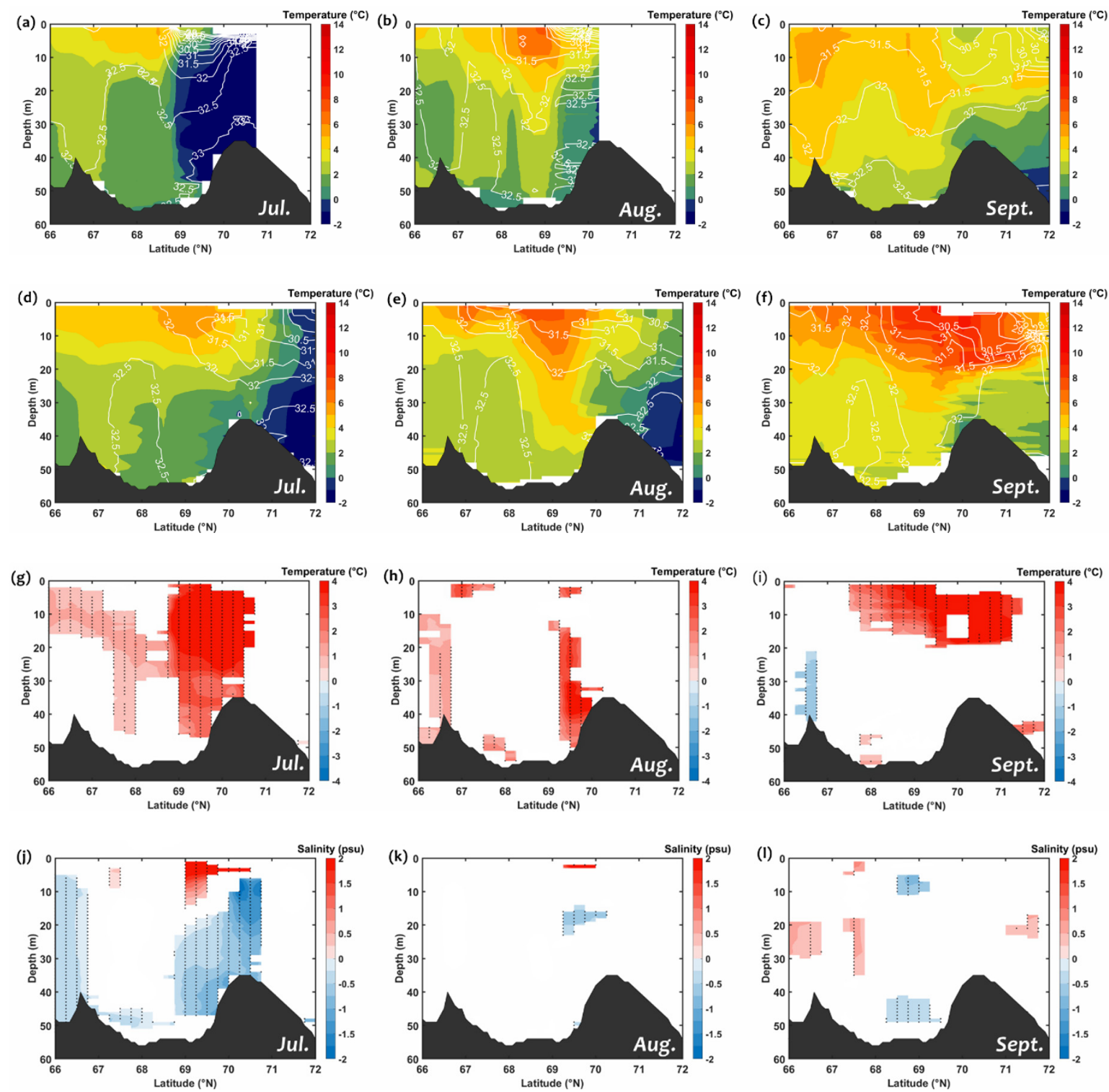

Figure 12. Multi-year mean vertical sections of the temperature (shaded) and salinity (contour) and their differences along $169^{\circ} \mathrm{W}$ from July to September in $(\mathbf{a}-\mathbf{c})$ pre- and $(\mathbf{d}-\mathbf{f})$ post-1997 periods, respectively; Differences in the $(\mathbf{g}-\mathbf{i})$ temperature and $(\mathbf{j}-\mathbf{l})$ salinity between the two periods. The color shaded areas and the blank dots in difference maps indicate $95 \%$ and $99 \%$ confidence level, respectively.

The striking feature in the bottom layer is the northward extension of the PSW and retreat of the PWW after 1997 (Figure 11a-d). The PWW was north of $69.5^{\circ} \mathrm{N}$ and covered the northeastern Chukchi shelf and slope before 1997 (Figure 11a,c). After 1997, the PWW shrank to north of $71.5^{\circ} \mathrm{N}$, which has led to significant warming and freshening between the Herald and Hanna Shoal in the bottom layer (Figure 11e,f).

The vertical sections along $169^{\circ} \mathrm{W}$ in July, August, and September of the two periods display the monthly evolutions and progress of the water masses (Figure 12). The PSW progressed northward, while the PWW retreated to the north. The mixed layer deepened, and the surface heating phenomenon shifted downward from July to September. Moreover, in September, the thermocline was not as sharp as those in July and August.

The comparison of the vertical sections of the two periods shows that the seasonal progress of the water masses along $169^{\circ} \mathrm{W}$ after 1997 occurred approximately a month earlier than before, thereby leading to significant changes in the water properties. For example, in July, the north edge 
of the warm PSW was approximately at $69^{\circ} \mathrm{N}$ pre- 1997 and approximately at $71^{\circ} \mathrm{N}$ post- 1997 . In September pre-1997, the subduction of the ACW led to a subsurface temperature maximum at a depth of approximately 20-30 m north of $69^{\circ} \mathrm{N}$; the feature was not evident post-1997 because the entire upper layer was heated.

The difference in 95\% confidence level shows that the temperature increased after 1997 each month (Figure $12 \mathrm{~g}-\mathrm{i}$ ). The remarkable warming at the front near $69^{\circ}-70^{\circ} \mathrm{N}$ in July was due to the advection of the PSW, and the warming in the upper layer (less than $20 \mathrm{~m}$ ) in September was mainly due to the longer surface heating because of the earlier melting of the sea-ice cover after 1997. In July, salinity increased in the upper layer and decreased in the lower layer. In general, the changes in salinity were small in August and September along this meridional section (Figure 12j-1). The areas undergoing significant changes are small in August, especially in salinity difference maps. In August and September, PSW already occupied almost the whole shelf during the two periods, and the salinity of the PSW is more conservative than its temperature. The advection effect of the PSW become less important than surface forcing (wind mixing and surface heating) in August and September.

\subsubsection{Changes in Vertical Thermohaline Structure}

Because of earlier sea ice retreat, longer exposure of the shelf water, and the advancing Pacific inflow, the Chukchi Sea exhibits several regions with different water characteristics. The southern, central and northern subregions of the eastern Chukchi shelf (CS) were studied to understand the different responses in vertical thermohaline structures. The green and red lines in Figures 13-15 are regional mean vertical profiles of temperature and salinity for the pre- and post-1997 periods, respectively.
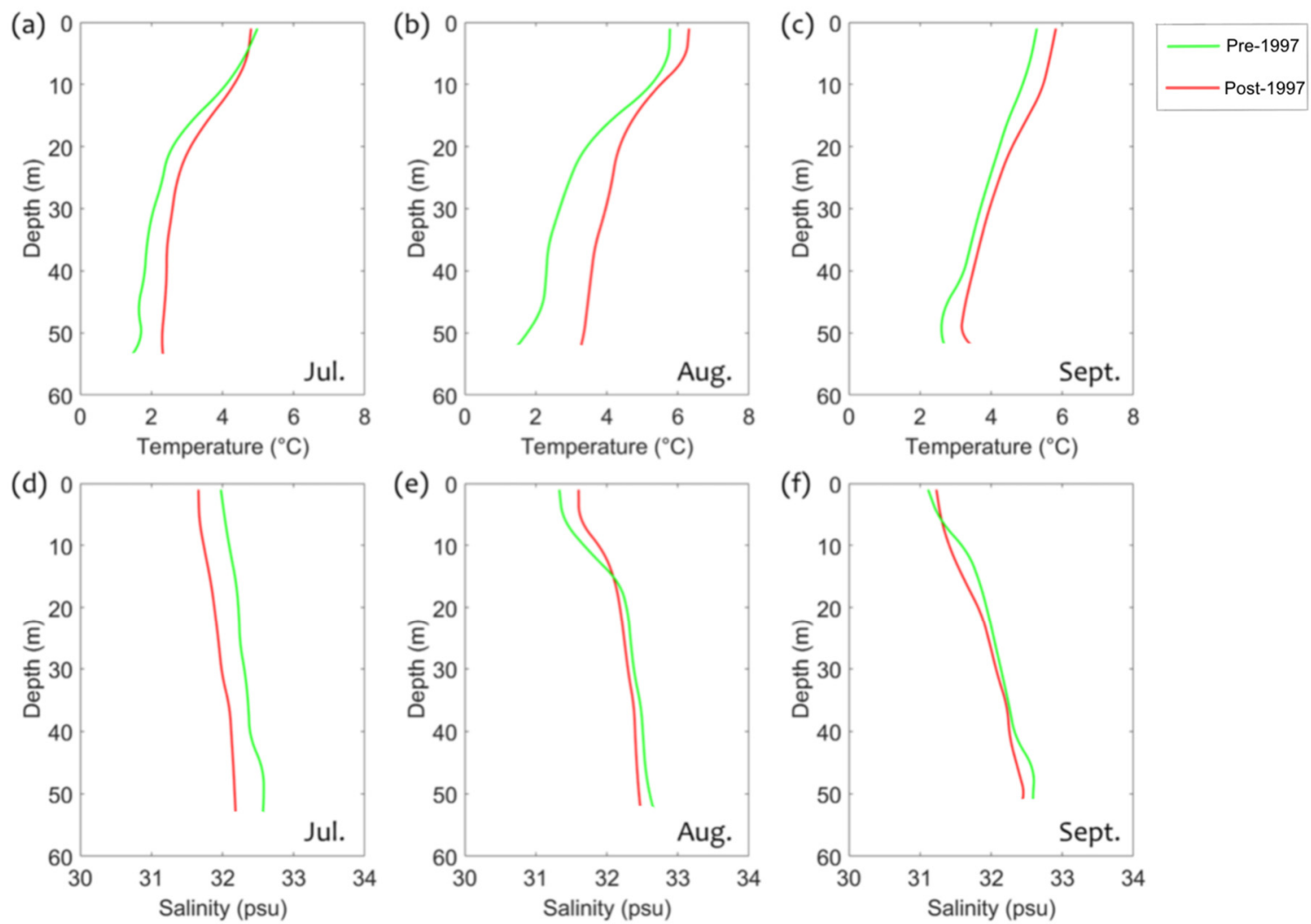

Figure 13. The regional average $(\mathbf{a}-\mathbf{c}) \mathrm{T}$ and $(\mathbf{d}-\mathbf{f}) \mathrm{S}$ profiles of the southern Chukchi shelf from July to September. The green and red lines represent the average values of the pre- and post-1997 periods, respectively. 

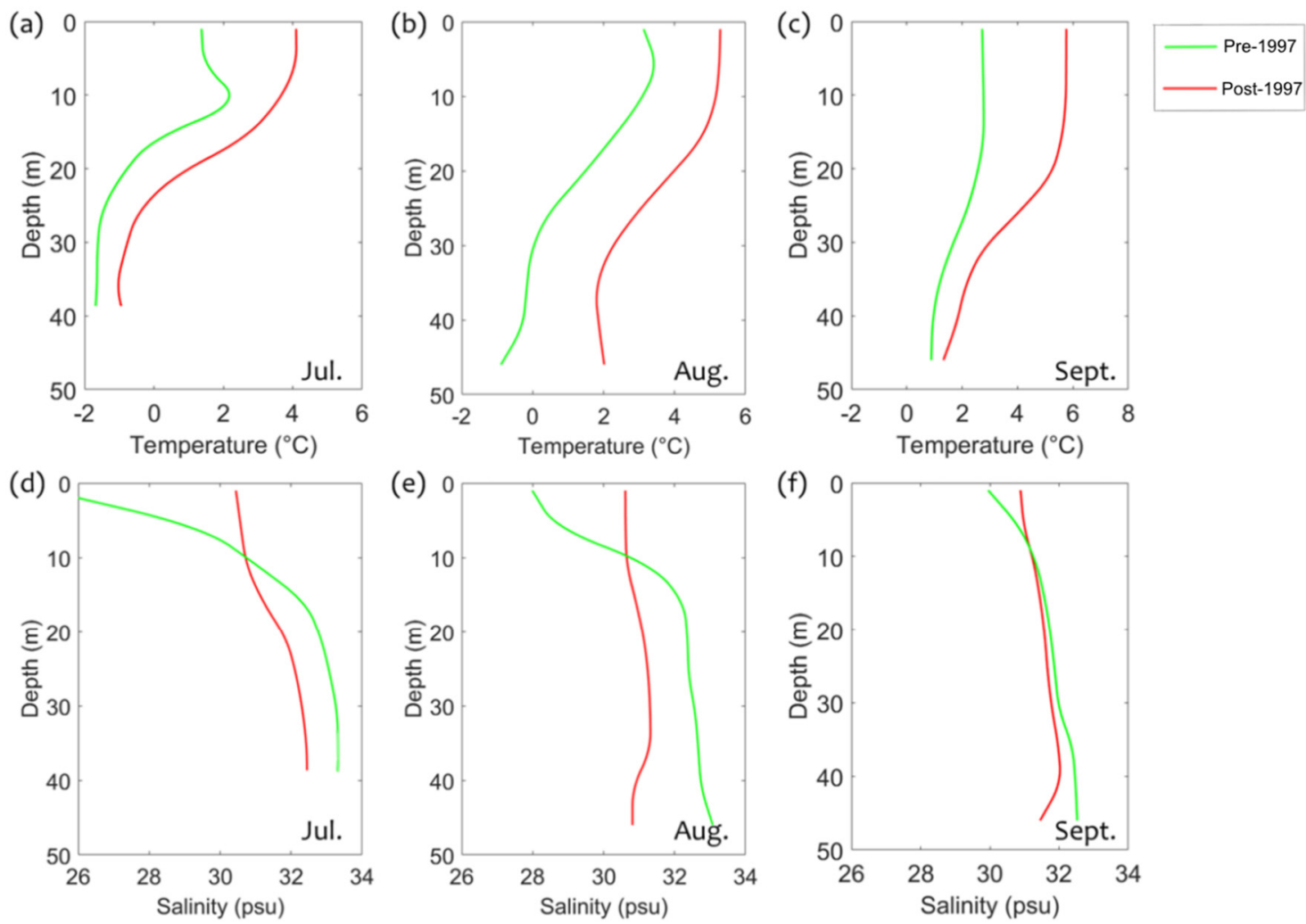

Figure 14. The regional average $(\mathbf{a}-\mathbf{c}) \mathrm{T}$ and $(\mathbf{d}-\mathbf{f}) \mathrm{S}$ profiles of the central Chukchi shelf from July to September. The green and red lines represent the average values of the pre- and post-1997 periods, respectively.
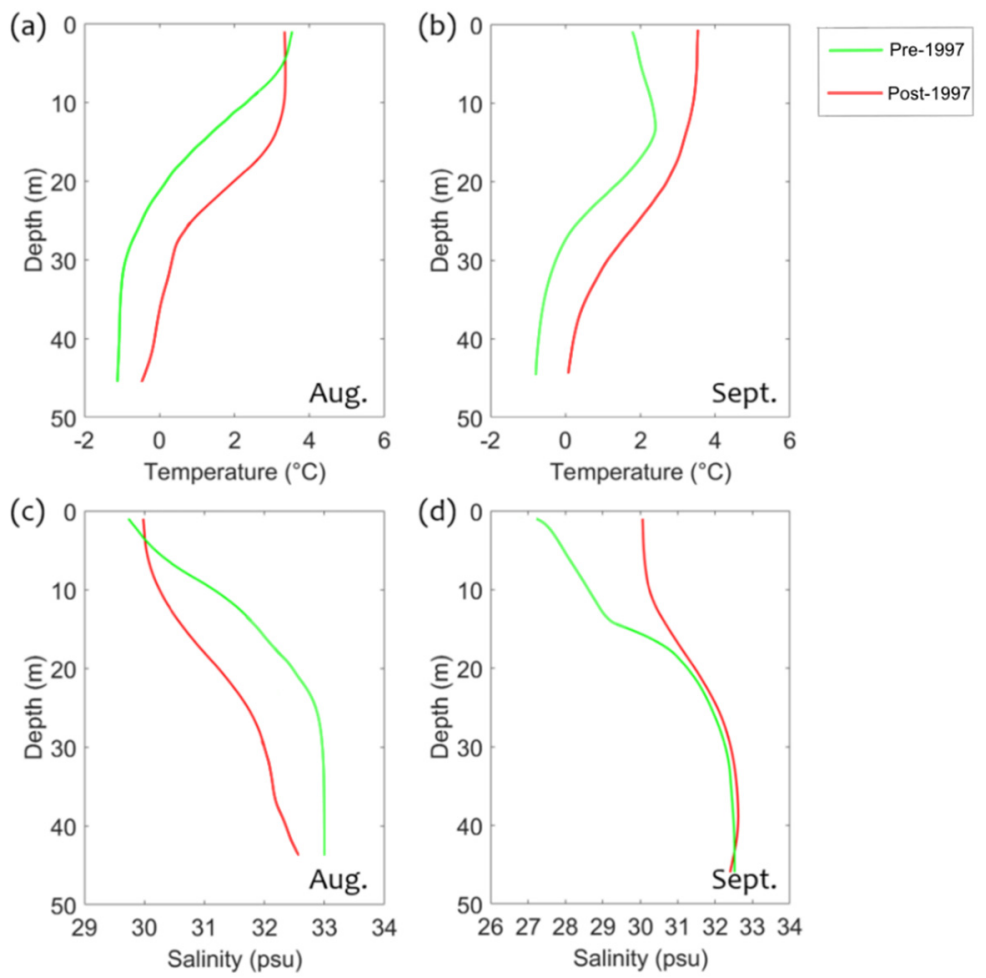

Figure 15. The regional average $(\mathbf{a}, \mathbf{b}) \mathrm{T}$ and $(\mathbf{c}, \mathbf{d}) \mathrm{S}$ profiles of the northern Chukchi shelf in August and September. The green and red lines represent the average values of the pre- and post-1997 periods, respectively. 


\section{(1) Southern CS}

This region is located near the entrance of the warm Pacific inflow (Figure 13). Owing to a similar ice-melting time before and after 1997, the T and S profiles of the two periods are similar. Two main water masses (ACW and BSW) dominate the region. The two water masses occasionally intersect with each other when flowing poleward owing to the topography.

The T and S profiles exhibit ACW in the surface layer and BSW in the deeper layer during both periods. In addition, the water columns were roughly mixed with weak stratification, and the mixed layer is shallow (5-10 m). The whole water columns during post-1997 was warmer than pre-1997.

\section{(2) Central CS}

This region is the frontier of the Pacific summer inflow. Owing to an ice melting time that was 50-60 days earlier during post-1997 than during pre-1997, the T and S profiles were strongly influenced by the Pacific inflow and surface heating.

In the pre-1997 period (green lines in Figure 14), because of the early_SMW in the top, the mixed water (BSW/CSW) in the subsurface and the PWW in the bottom layer, the T-profiles in July and August feature a multi-layer structure (shallow mixed layer, entrainment zone, upper and lower thermoclines, and a sublayer [34]) with a nose-shaped curve in the upper thermocline that has a maximal temperature at $10 \mathrm{~m}$. The multi-layer structure in August is, however, not as obvious as that in July. Meanwhile, the $S$ profiles show a steep halocline at 5-15 $\mathrm{m}$ depth, which separated the fresh water in the mixed layer and salty water in the deeper layer.

In post-1997 period (red lines in Figure 14), the T profiles are of a two-layer structure. The maximal subsurface temperature and steep halocline in July and August pre-1997 disappeared after 1997. Salinity mixed from July, which was two months earlier than before. The strong mixing redistributed the salt in the water column, resulting in an increased salinity in the upper layer and decreased salinity in the bottom layer.

\section{(3) Northern CS}

No data from this region for July are available because the region is near the ice edge. After the acceleration of sea ice reduction around 1997, the ice-free season in this region was prolongated (Figure 8c), thereby resulting in significant changes in the vertical structure (Figure 15).

The T and S profiles of pre-1997 Augusts are a two-layer system that consists of a surface mixed layer above a bottom boundary layer, separated by a sharp interface at $10 \mathrm{~m}$ depth. The ACW occupied the upper layer and the PWW the deep layer. The T profiles of Septembers are nose-shaped curves with the maximal subsurface temperature at $15-25 \mathrm{~m}$ depth, which is associated with the eastward-flowing BSW. After 1997, the T and S profiles become a two-layer system. Compared with that of the pre-1997 period, the two-layer system shifted downward, and the sharp interface deepened (from $10 \mathrm{~m}$ to $20 \mathrm{~m}$ ) in August.

\section{Discussion and Conclusions}

In this study, we have addressed the general hydrographic characteristics of the Chukchi Sea during summer and the associated regional changes from 1972 through 2017 by using a large amount of hydrographic data from the World Ocean Database 2013 and the Chinese National Arctic Research Expedition.

The Arctic ocean has been losing its summer ice cover over the past decades. Daily evolution of sea ice concentration shows that ice-free seasonal phases in the central Chukchi shelf after 1997 is approximately 50-60 days longer than before 1997 (Figure 8). The results correspond to the facts that the decline rate of Arctic sea ice accelerated after 1997 [18]. One of the potential reasons may be that the trend of net surface heat fluxes over the Chukchi Sea has shifted from a negative trend of $-1.1 \mathrm{~W} / \mathrm{m}^{2} /$ year in 1983-1997 to a positive trend of 0.7 W/m²/year in 1997-2017 (Figure 6). Steele et al. 
(2008) [25] found that the Arctic surface warming is particularly pronounced since 1995, and especially since 2000. All these phenomena suggest that perhaps there was a climate regime shift around 1997, though the cause of this shift is still unclear. The possible interpretation is that sea ice retreat creates a longer ice-free season on the shelf, which certainly affects the surface forcing by allowing enhanced wind mixing [35], turbulence heat fluxes and extra solar radiation absorbing, etc. In addition to the changes in surface forcing, heat transport from the Pacific Ocean through Bering Strait increased by 60\% during 2001-2014, which was attributed to increases in both volume flux and temperature [4]. These two effects all contribute to the changes in the Chukchi shelf.

As an inflow shelf, the Chukchi Sea is heavily influence by the Pacific inflow, and the oceanic advection effect is expected to be weaker approaching the northern shelf. Based on the comparison of summer hydrography between the pre- and post-1997 periods, our results suggest that the north extension of the PSW is the primary driver for the hydrographic changes in the Chukchi shelf. The data shows that the edge of PSW at the surface (bottom) was located at approximately $70^{\circ} \mathrm{N}\left(69.5^{\circ} \mathrm{N}\right)$ before 1997 and $72^{\circ} \mathrm{N}\left(71.5^{\circ} \mathrm{N}\right)$ after 1997 (Figures 10 and 11). The surface edge position of PWS over post-1997 period was close to the averaged dominate current using satellite-tracked drifters for 2010-2015 [36], which indicates the Pacific inflow may be the factor causing the hydrographic change post-1997 period. The PSW replaced the fresh and cold melting water at the surface, and pushed the PWW northward at the depth. The differences in the thermohaline along $169^{\circ} \mathrm{W}$ also demonstrate the influences of the extending PSW (Figure 12). The results are in accordance with the observed increase of the Pacific inflow [4,37].

Given differences in timing of sea ice melting, effects of the Pacific inflow [37] and local circulations that are steered by the complex local topography [32], the responses in the Chukchi Sea to the sea ice retreat are not uniform. On the southern shelf, due to the relatively stable effect of the Pacific inflow and similar ice conditions during the two periods, the area-averaged temperature and salinity as well as the vertical thermohaline structures did not show evident changes (Figures 5 and 13). However, as the frontier area of the PSW, the central shelf has experienced significant changes due to the increased Pacific inflow. It has been warming since 1972 with a linear trend of $+0.67^{\circ} \mathrm{C} /$ decade. The surface salinity has a positive trend and the bottom salinity has a negative trend (Figure 5), implying that the vertical structure of the salinity has changed. The possible explanation is the northward extension of the PSW. Before 1997, the central shelf water column consisted of fresh melting water in the surface and the PWW near the bottom. After 1997, the whole water column was replaced by the PSW. Previous study of the increase in the Pacific inflow to the Arctic over 1990-2015 [37] well supported the northward extension of the PSW after 1997. The T and S profiles also confirm such changes (Figure 14). The increasing Pacific inflow also acted as increasing the heat flux and study found that the $\sim 67 \%$ of the total heat input to the sea water in Chukchi Sea was from Pacific inflow and then of 58\% heat input was used to further heat sea water [38], which may interpret the warming in the central shelf. The oceanic advection effects on the northern shelf become weaker, while surface forcing may play a bigger role in water property and vertical structure changes.

It is clearly that the Chukchi Sea are influenced by both oceanic advection and surface forcing simultaneously, and it remains a challenge to distinguish between the effects of oceanic advection and sea ice retreat. Using the coupled ocean and sea ice model, Wang et al., (2019) [38] found that the Pacific inflow heat flux acted more significant impacts on the interannual variations of Chukchi Sea ice cover than the net heat flux at ice surface during 1994-2015, but their contributions will change for different stages of ice melting. Our results also suggest that the relative roles of the two effects may vary with region and months during the summer season. For example, the changes in meridional section along $169^{\circ} \mathrm{W}$ (Figure 12) are most significant in July due to the north extension of the PSW, however, the effect of oceanic advection become less important in August and September, because the northern edges of the PSW are close in both periods, and the changes in hydrography are mainly induced by enhanced wind mixing and surface heating that are caused by sea ice retreat. The sparsity and discontinuity of the observations make it difficult to evaluate the relative roles of the oceanic 
advection and sea ice retreat. Further analysis and idealized numerical experiments should be useful to discuss the mechanisms and relationships of these factors.

Author Contributions: Conceptualization, X.B.; data curation, Y.Y.; formal analysis, Y.Y. and X.B.; funding acquisition, X.B.; investigation, Y.Y.; project administration, X.B.; writing-original draft, Y.Y.; writing一review and editing, X.B. All authors have read and agreed to the published version of the manuscript.

Funding: This work was supported by the National Key Research and Development Program of China (Grant 2017YFA0604600), Postgraduate Research \& Practice Innovation Program of Jiangsu Province (Grant SJKY19_0417), the Fundamental Research Funds for the Central Universities (Grant 2019B63014) and National Natural Science Foundation of China (Grant 41676019).

Acknowledgments: The authors wish to acknowledge the National Oceanographic Data Centre (NODC, https: //www.nodc.noaa.gov) and the National Arctic and Antarctic Data Center (http://www.chinare.org.cn) for providing the temperature and salinity data of the Chukchi Sea, the National Snow and Ice Data Center (NSIDC, https://nsidc.org/data/) for providing sea-ice data. We sincerely thank the anonymous reviewers for their critical and constructive comments, which helped significantly improve the analysis and presentation of the paper.

Conflicts of Interest: The authors declare no conflict of interest.

\section{References}

1. Woodgate, R.A.; Aagaard, K.; Weingartner, T.J. Monthly temperature, salinity, and transport variability of the Bering Strait through inflow. Geophys. Res. Lett. 2005, 32, L04601. [CrossRef]

2. Steele, M.; Morison, J.; Ermold, W.; Rigor, I.; Ortmeyer, M.; Shimada, K. Circulation of summer Pacific halocline water in the Arctic Ocean. J. Geophys. Res. 2004, 109, C02027. [CrossRef]

3. Shimada, K.; Kamoshida, T.; Itoh, M.; Nishino, S.; Carmack, E.; McLaughlin, F.; Zimmermann, S.; Proshutinsky, A. Pacific Ocean inflow: Influence on catastrophic reduction of sea-ice cover in the Arctic Ocean. Geophys. Res. Lett. 2006, 33, 153-172. [CrossRef]

4. Woodgate, R.A.; Weingartner, T.; Lindsay, R. The 2007 Bering Strait oceanic heat flux and anomalous Arctic sea-ice retreat. Geophys. Res. Lett. 2010, 37, L01602. [CrossRef]

5. Spall, M.A.; Pickart, R.S.; Li, M.; Itoh, M.; Lin, P.; Kikuchi, T.; Qi, Y. Transport of Pacific water into the Canada Basin and the formation of the Chukchi Slope Current. J. Geophys. Res. Ocean. 2018, 123, 7453-7471. [CrossRef]

6. Wang, J.; Zhang, J.; Watanabe, E.; Ikeda, M.; Mizobata, K.; Walsh, J.E.; Bai, X.; Wu, B. Is the Dipole Anomaly a major driver to record lows in Arctic summer sea ice extent? Geophys. Res. Lett. 2009, 36, 277-291. [CrossRef]

7. Stroeve, J.C.; Maslanik, J.; Serreze, M.C.; Rigor, I.; Meier, W.; Fowler, C. Sea ice response to an extreme negative phase of the Arctic Oscillation during winter 2009/2010. Geophys. Res. Lett. 2011, 38, 79-89. [CrossRef]

8. Springer, A.M.; McRoy, C.P. The paradox of pelagic food webs in the northern Bering Sea-III. Patterns of primary productivity. Cont. Shelf Res. 1993, 13, 575-599. [CrossRef]

9. Hunt, G.L., Jr.; Blanchard, A.L.; Boveng, P.; Dalpadado, P.; Drinkwater, K.F.; Eisner, L.; Hopcroft, R.R.; Kovacs, K.M.; Norcross, B.L.; Renaud, P.; et al. The Barents and Chukchi Seas: Comparison of two Arctic shelf ecosystems. J. Mar. Syst. 2013, 109, 43-68. [CrossRef]

10. Coachman, D.J.; Lawrence, K. Bering Strait: The Regional Physical Oceanography; University of Washington Press: Seattle, WA, USA, 1975.

11. Shimada, K.; Carmack, E.C.; Hatakeyama, K.; Takizawa, T. Varieties of shallow temperature maximum waters in the western Canadian Basin of the Arctic Ocean. Geophys. Res. Lett. 2001, 28, 3441-3444. [CrossRef]

12. Gong, D.; Pickart, R.S. Summertime circulation in the eastern Chukchi Sea. Deep. Sea Res. Part II Top. Stud. Oceanogr. 2015, 118, 18-31. [CrossRef]

13. Pisareva, M. An overview of the recent research on the Chukchi Sea water masses and their circulation. Russ. J. Earth Sci. 2018, 18, 1-13. [CrossRef]

14. Linders, J.; Pickart, R.; Björk, G.; Moore, G. On the nature and origin of water masses in Herald Canyon, Chukchi Sea: Synoptic surveys in summer 2004, 2008, and 2009. Prog. Oceanogr. 2017, 159, 99-114. [CrossRef]

15. Aagaard, K.; Swift, J.; Carmack, E.C. Thermohaline circulation in the Arctic Mediterranean Seas. J. Geophys. Res. Space Phys. 1985, 90, 4833. [CrossRef]

16. Newton, J.L.; Sotirin, B.J. Boundary undercurrent and water mass changes in the Lincoln Sea. J. Geophys. Res. Space Phys. 1997, 102, 3393-3403. [CrossRef] 
17. Perovich, D.K.; Light, B.; Eicken, H.; Jones, K.F.; Runciman, K.; Nghiem, S. Increasing solar heating of the Arctic Ocean and adjacent seas, 1979-2005: Attribution and role in the ice-albedo feedback. Geophys. Res. Lett. 2007, 34, L19505. [CrossRef]

18. Comiso, J.C.; Parkinson, C.L.; Gersten, R.; Stock, L. Accelerated decline in the Arctic sea ice cover. Geophys. Res. Lett. 2008, 35. [CrossRef]

19. Stroeve, J.C.; Serreze, M.C.; Holland, M.M.; Kay, J.E.; Malanik, J.; Barrett, A.P. The Arctic's rapidly shrinking sea ice cover: A research synthesis. Clim. Chang. 2012, 110, 1005-1027. [CrossRef]

20. Woodgate, R.; Aagaard, K.; Weingartner, T.J. Interannual changes in the Bering Strait fluxes of volume, heat and freshwater between 1991 and 2004. Geophys. Res. Lett. 2006, 33, L15609. [CrossRef]

21. Timmermans, M.-L. The impact of stored solar heat on Arctic sea ice growth. Geophys. Res. Lett. 2015, 42, 6399-6406. [CrossRef]

22. Steele, M.; Zhang, J.; Ermold, W. Mechanisms of summertime upper Arctic Ocean warming and the effect on sea ice melt. J. Geophys. Res. Space Phys. 2010, 115, C11004. [CrossRef]

23. Screen, J.; Simmonds, I. The central role of diminishing sea ice in recent Arctic temperature amplification. Nature 2010, 464, 1334-1337. [CrossRef] [PubMed]

24. Cohen, J.; Screen, J.A.; Furtado, J.C.; Barlow, M.; Whittleston, D.; Coumou, D.; Francis, J.; Dethloff, K.; Entekhabi, D.; Overland, J.; et al. Recent Arctic amplification and extreme mid-latitude weather. Nat. Geosci. 2014, 7, 627-637. [CrossRef]

25. Steele, M.; Ermold, W.; Zhang, J. L Arctic Ocean surface warming trends over the past 100 years. Geophys. Res. Lett. 2008, 35, L02614. [CrossRef]

26. Bai, X.; Hu, H.; Wang, J.; Yu, Y.; Cassano, E.; Maslanik, J. Responses of surface heat flux, sea ice, and ocean dynamics in the Chukchi-Beaufort Sea o storm passages during winter 2006/2007: A numerical study. Deep Sea Res. I 2015, 102, 101-117. [CrossRef]

27. Boyer, T.P.; Antonov, J.I.; Baranova, O.K.; Coleman, C.; Garcia, H.E.; Grodsky, A.; Johnson, D.R.; Locarnini, R.A.; Mishonov, A.V.; O’Brien, T.D.; et al. World Ocean Database 2013; Levitus, S., Mishonov, A., Eds.; NOAA Atlas NESDIS: Silver Spring, MD, USA, 2013; Volume 209, pp. 29-30.

28. Von Appen, W.; Pickart, R.S. Two Configurations of the Western Arctic Shelfbreak Current in Summer. J. Phys. Oceanogr. 2012, 42, 329-351. [CrossRef]

29. Martin, S.; Drucker, R. The effect of possible Taylor columns on the summer ice retreat in the Chukchi Sea. J. Geophys. Res. Space Phys. 1997, 102, 10473-10482. [CrossRef]

30. Ahlnäs, K.; Garrison, G.R. Satellite and oceanographic observations of the warm coastal current in the Chukchi Sea. Arctic 1984, 37, 244-254. [CrossRef]

31. Overland, J.E.; Roach, A.T. Northward flow in the Bering and Chukchi seas. J. Geophys. Res. Space Phys. 1987, 92, 7097. [CrossRef]

32. Corlett, W.B.; Pickart, R.S. The Chukchi slope current. Prog. Oceanogr. 2017, 153, 50-65. [CrossRef]

33. Itoh, M.; Shimada, K.; Kamoshida, T.; McLaughlin, F.; Carmack, E.; Nishino, S. Interannual variability of Pacific Winter Water inflow through Barrow Canyon from 2000 to 2006. J. Oceanogr. 2012, 68, 575-592. [CrossRef]

34. Chu, P.C.; Wang, Q.; Bourke, R.H. A Geometric Model for the Beaufort/Chukchi Sea Thermohaline Structure. J. Atmos. Ocean. Technol. 1999, 16, 613-632. [CrossRef]

35. Liang, M.; Shi, J. Variations in coastal polynyas in the Alaskan Chukchi Sea and major influencing factors. Chin. J. Polar Res. 2015, 27, 379-391. [CrossRef]

36. Spear, A.; Duffy-Anderson, J.; Kimmel, D.; Napp, J.; Randall, J.; Stabeno, P. Physical and biological drivers of zooplankton communities in the Chukchi Sea. Polar Biol. 2019, 42, 1107-1124. [CrossRef]

37. Woodgate, R.A. Increases in the Pacific inflow to the Arctic from 1990 to 2015, and insights into seasonal trends and driving mechanisms from year-round Bering Strait mooring data. Prog. Oceanogr 2018, 160, 124-154. [CrossRef]

38. Wang, Y.; Luo, X.; Zhang, Y.; Qin, Y.; Zhao, W.; Zheng, Z.; Nie, H.; Wei, H. Heat budget analysis during the ice-melting season in the Chukchi Sea based on a model simulation. Chin. Sci. Bull. 2019, 64, 3485-3497.

(C) 2020 by the authors. Licensee MDPI, Basel, Switzerland. This article is an open access article distributed under the terms and conditions of the Creative Commons Attribution (CC BY) license (http://creativecommons.org/licenses/by/4.0/). 